\title{
Tetranychus mexicanus (Acari: Tetranychidae) in soursop seedlings in the state of Mato Grosso do Sul, Brazil
}

\author{
Eliamara Marques Silva ${ }^{1}$, Luciana Cláudia Toscano ${ }^{1}$, Fábio Steiner ${ }^{1}$, Wilson Itamar \\ Maruyama $^{1}$ \\ ${ }^{1}$ Universidade Estadual de Mato Grosso do Sul, Unidade Universitária de Cassilândia, Cassilândia, Mato Grosso do Sul, Brasil. \\ E-mail: eliamaramarques@outlook.com, toscano@uems.br, steiner@uems.br,wilsonmaruyama@uems.br
}

Received: 27/05/2019; Accepted: 31/10/2019.

\section{ABSTRACT}

Phytophagous mites belonging to the family Tetranychidae are considered pests of a wide range of plant species of agricultural importance in the Annonaceae family. This study aimed to reports the occurrence and attack symptoms of the mite Tetranychus mexicanus (McGregor) (Acari: Tetranychidae) on soursop seedlings (Anonna muricata L.). High mite infestation on the leaves of soursop seedlings was reported in a seedling production nursery made of black Sombrite ${ }^{\circledR}$ screen with $35 \%$ restriction of full daylight, located at the State University of Mato Grosso do Sul (UEMS), in Cassilândia, MS, Brazil, during the month of October 2015. Attack symptoms were on the adaxial side of the leaves, whereas mite colonies were located on the abaxial face of the leaves. The injuries started by yellowing of the leaves and curled edges, and later by the fall of the attacked leaves. This is the first record of the occurrence of T. mexicanus in soursop seedlings produced on agricultural screenhouse in the state of Mato Grosso do Sul, Brazil.

Keywords: Acari, damage, Anonna muricata.

\section{Tetranychus mexicanus (Acari: Tetranychidae) em mudas de graviola no estado de Mato Grosso do Sul}

\section{RESUMO}

Ácaros da família Tetranychidae são considerados pragas em espécies de plantas da família Annonaceae de importância agrícola. Este estudo teve como objetivo relatar a ocorrência e os sintomas de ataque do ácaro Tetranychus mexicanus (McGregor) (Acari: Tetranychidae) em mudas de graviola (Anonna muricata L.). Foi verificada alta infestação de ácaros sobre as folhas de mudas de graviola produzidas em viveiro de mudas, com tela de $35 \%$ de sombreamento (Sombrite ${ }^{\circledR}$ ), localizado na Universidade Estadual de Mato Grosso do Sul - UEMS, em Cassilândia - MS, durante o mês de outubro de 2015. Os sintomas de ataque foram verificados na face adaxial das folhas, enquanto as colônias dos ácaros se localizavam na face abaxial. As injúrias observadas iniciaram-se pelo amarelecimento das folhas e bordos enrolados, e, posteriormente, pela queda das folhas atacadas. Este é o primeiro registro da ocorrência de T. mexicanus em mudas de graviola produzidas em telados agrícolas no Estado de Mato Grosso do Sul.

Palavras-chave: Acari, danos, Anonna muricata. 
Soursop [Annona muricata L., (Annonaceae)], commonly known in Brazil as "graviola", is a fruit tree native to the tropical regions of the Americas and the Caribbean and is currently widely distributed in tropical regions around the world for its edible fruit. In Brazil, soursop can be found in the rain forest and savannah biome zone either domesticated or growing wild (Souza et al., 2003). This species is considered the second Annonaceae in cultivated area and in production in Brazil, being surpassed only by the sweetsop crop (Annona squamosa L.) (Lemos, 2014).

There is little technical information about the soursop culture in Brazil. However, the cultivation of this species has grown in recent years in several regions of Brazil (Lima, 2004). In the Midwest region of Brazil, a total of 69 tons of this fruit were produced in an area of only 18 ha (IBGE, 2009). According to Lazzarotto et al. (2005), sufficiency in fruit production in the state of Mato Grosso do Sul has long been an objective of the productive sectors, however, some factors are limiting for this growth in fruit production.

Seedling production is a fundamental phase to obtain uniformity of soursop plants (Costa et al., 2016). At this stage of production, the type of substrate, production environment, irrigation, fertilization, and correct phytosanitary management provide conditions for obtaining high-quality seedlings, ensuring success in the development of plants in the field (Costa et al., 2015).

Lemos (2014) reported the occurrence of several pests, such as insects and mites in the soursop crop, which are responsible for economic damage. Reports on the mite Tetranychus mexicanus (McGregor) (Acari: Tetranychidae) in several species belonging to the family Annonaceae, such as Annona reticulata L. (wildsweetsop), Annona squamosa L. (sweetsop), Annona cherimola Mill. (cherimoya) and the hybrid $A$. cherimola $\times A$. squamosa (atemoya) have been frequent, making this species a pest of these crops (Sousa et al., 2015).

Sousa et al. (2010) reported that the higher longevity of males and the highest oviposition observed in this species of mite are verified when they feed on soursop plants compared to other Annonaceae, such as sweetsop (Annona squamosa) or araticum (Annona coriaceae). In general, when feeding, tetraniquids damage the leaf parenchyma cells, causing injuries that cause chlorosis, necrosis, deformation and subsequently they may dry and fall (Moraes and Flechtmann, 2008). According to Sousa et al. (2015), when high T. mexicanus populations occur in healthy fruits, there is intense fruit darkening, reduction in size and hardening of the pulp.

The first reports of the species T. mexicanus occurred in the United States of America (Texas), Mexico and Argentina, in citrus plants (Flechtmann and Baker, 1970). In Brazil, this mite is mainly reported in fruit such as coconut tree (Cocos nucifera L., Arecaceae), citrus (Citrus spp., Rutaceae), banana (Musa spp., Musaceae), papaya (Carica papaya L., Caricaceae), passion fruit (Passiflora spp., Passifloraceae) and species of the family Rosaceae [apple tree (Pyrus malus L.); common quince (Cydonia oblonga P.); common pear (Pyrus communis L.)] (Moraes and Flechtmann, 2008).

Although there is information on the attack of Tetraniquidae mites on fruits and leaves of soursop trees, there is a lack of information on the behavior of this mite on soursop seedlings grown in protected environments. Thus, the aim of this study was to report the occurrence and symptoms of T. mexicanus mite attack on soursop seedlings.

The study was conducted at the State University of Mato Grosso do Sul (UEMS), in Cassilândia, MS, Brazil $\left(19^{\circ} 05^{\prime} 20^{\prime \prime} \mathrm{S}, 51^{\circ} 48^{\prime} 24^{\prime \prime} \mathrm{W}\right.$, and altitude of 510 $\mathrm{m})$. The regional climate according to the Köppen classification is Aw, characterized as a tropical climate with hot summers and a tendency towards high rainfall levels, and dry winters, with a dry season between May and September. The mean annual temperature is $24.1^{\circ} \mathrm{C}$ with a July minimum of $16.4{ }^{\circ} \mathrm{C}$ and a January maximum of $28.6^{\circ} \mathrm{C}$, and mean annual rainfall of 1,240 to $1,520 \mathrm{~mm}$.

The soursop seedlings were grown in black polyethylene bags of $20.0 \times 25.0 \mathrm{~cm}(2.5 \mathrm{~L})$, filled with different proportions of bovine manure, soil, sand, carbonized rice hull, and vermiculite. The seedlings were grown in two seedlings production environments: full sunlight and in a seedling production nursery constructed of black Sombrite ${ }^{\circledR}$ screen with 35\% restriction of full daylight. The seedlings were watered daily and maintained in theses seedlings production environments for up to 120 days.

During the month of October 2015, a high population of mites was reported on leaves of the soursop seedlings of about 60 days. However, symptoms of mite attack were only observed in soursop seedlings grown in the protected environment (seedling production nursery). Mites present in the leaves of the seedlings were collected with the aid of a brush with fine bristles and placed in containers filled with $70 \%$ alcohol. Subsequently, the mites were sent to the Acarology Laboratory of the Biological Institute of São Paulo, in Campinas, SP, Brazil. The slides of the individuals used for identification were deposited in the Museum of Acarology of the Biological Institute of São Paulo.

The mite was identified as $T$. mexicanus, according to Gutierrez (1968) and Jepson et al. (1975). Attack symptoms were on the adaxial side of the leaves, whereas mite colonies were located on the abaxial face of the leaves. 
With the aid of a stereoscopic microscope (40x), it was observed the presence of small trichomes on the leaf face where the mites were not located (adaxial). The observed injuries initiated by yellowing of the leaves and curled edges, and then followed by the fall of the leaf. The symptom of mite attack always began in the lower third of the seedling canopy toward the upper third (Figure 1).

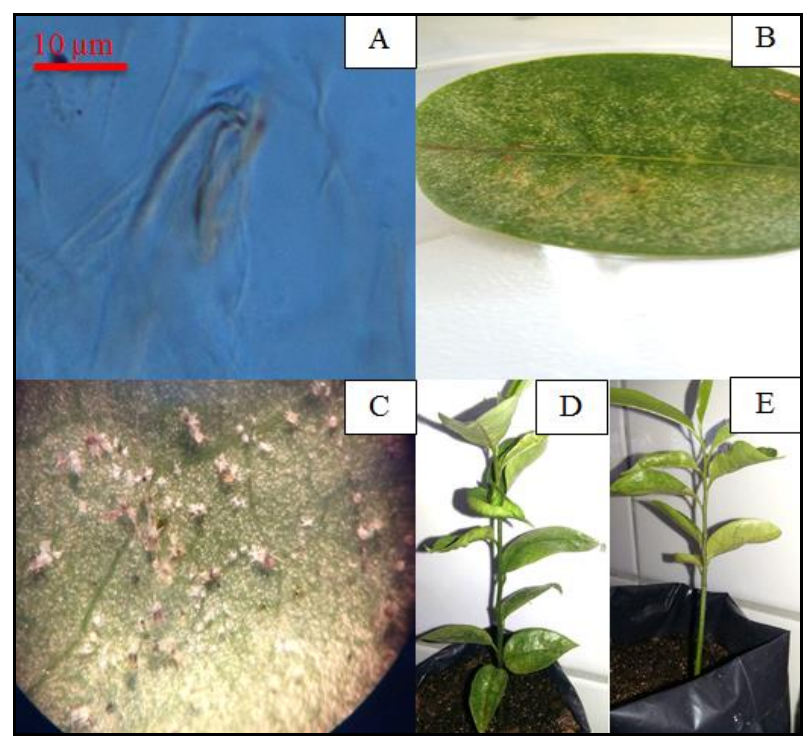

Figure 1. Tetranychus mexicanus in soursop seedlings (Annona muricata L. (Annonaceae)). (A) Tetranychus mexicanus edeago; (B) Attack symptom on the adaxial face of the soursop leaf; (C) T. mexicanus colony; (D-E) Soursop seedlings attacked by T. mexicanus.

There are no previous reports of the occurrence of mites in soursop seedlings in the state of Mato Grosso do Sul, Brazil. In northeastern Brazil, the first description of this species attacking soursop leaves was reported by Moraes and Flechtmann (1981). According to these authors, these mites have a reddish-green color when found on soursop and banana leaves. The proximal duplicate arrows of the tarsus I are located distally to the proximal tactile arrows and welldeveloped dorsomedial spur. Sousa et al. 2010 reported that the biological cycle of this mite on soursop leaves has a duration of 10 days, being the embryonic, larval, protonymph and deutonymph phases with average durations of $3.4 ; 2.6 ; 1.9$; and 2.3 days, respectively.

According to Vieira et al. (2004), the cultivation of seedlings in protected environments favors the population development of phytophagous mites, such as the white mite Polyphagotarsonemus latus (Banks) and the brindle mite Tetranychus urticae (Koch). Mites, as well as other terrestrial arthropods, they lose water by diffusion through the body (Moraes and Flechtmann, 2008). Thus, the protected environment may have favored the development of the population due to the higher humidity indices when compared to the exposure of the seedlings to the full sunlight environment.
Although there are some reports of the occurrence and existence of damage of $T$. mexicanus on soursop leaves and fruits, it is found that these reports occurred on adult plants (Moraes and Flechtmann, 1981; Moraes and Flechtmann, 2008; Sousa et al., 2015) and not in seedlings of this fruit species. Therefore, this is the first record of the occurrence of $T$. mexicanus in soursop seedlings produced on agricultural screenhouse in the state of Mato Grosso do Sul, Brazil. This report of damage to soursop seedlings in a protected cultivation environment is of great importance for proper phytosanitary management to produce high-quality seedlings.

\section{Acknowledgments}

To Dr. André Luiz Matioli (Biological Institute of Campinas, SP, Brazil), for the identification and confirmation of the mite species.

\section{Bibliographic References}

Costa, E., Dias, J.G., Lopes, K.G., Binotti, F.F.S., Cardoso, E.D., 2015. Telas de sombreamento e substratos na produção de mudas de Dipteryx alata Vog. Floresta e Ambiente, 22(3), 416-425.

Costa, E., Sassaqui, A.R., Silva, A.K., Rego, N.H., Fina, B.G., 2016. Soursop seedlings: biomasses and biometric relations in different farming environments and substrates - part II. Engenharia Agrícola, 36(2), 229-241.

Flechtmann, C.H.W., Baker, E.W., 1970. A preliminary report on the Tetranychidae (Acarina) of Brazil. Annals of the Entomological Society of America, 63(1), 156-163.

Gutierrez, J., 1968. Tetranychidae nouveaux de Madagascar (Quatrième note). Acarologia, 10(1), 13-28.

IBGE. Instituto Brasileiro de Geografia e Estatística, 2009. Censo agropecuário. Rio de Janeiro, 777 p. https://biblioteca.ibge.gov.br/visualizacao/periodicos/51/agro_ 2006.pdf (acessado 28 de setembro de 2018).

Jepson, L.R., Keifer, H.H., Baker, E.W., 1975. Mites injurious to economic plants. Berkeley, University of California Press.

Lazzarotto, C., Fornasieri, J.L., Comunello, E., Soriano, B.M.A., Araújo, M.R., Sandrini, M., 2005. Zoneamento para a fruticultura em Mato Grosso do Sul. Dourados: Embrapa Agropecuária Oeste, 39 p.

Lemos, E.E.P., 2014. A produção de anonáceas do Brasil. Revista Brasileira de Fruticultura, 36, 77-85.

Lima, M.A.C., 2004. O cultivo da gravioleira. Revista Brasileira de Fruticultura, 26(3), 385-566.

Moraes, G.J., Flechtmann, C.H.W., 1981. Ácaros fitófagos do Nordeste do Brasil. Pesquisa Agropecuária Brasileira, Brasília, 16(2), 177-186. 
Moraes, G.J., Flechtmann, C.H.W., 2008. Manual de acarologia. Holos, Ribeirão Preto.

Sousa, J.M., Gondim Junior, M.G.C., Lofego, A.C., 2010. Biologia de Tetranychus mexicanus (McGregor) (Acari:Tetranychidae) em três espécies de Annonaceae. Neotropical Entomology, 39(3), 319-323.

Sousa, J.M., Gondim Junior, M.G.C., Lofego, A.C., Moraes, G.J., 2015. Mites on Annonaceae species in northeast Brazil and in the state of Para. Acarologia, 55(1), 5-18.
Souza, C.A.S., Corrêa, F.L.O., Mendonça, V., Carvalho, J.G., 2003. Crescimento de mudas de gravioleira (Anonna muricata L.) em substrato com superfosfato simples e vermicomposto. Revista Brasileira Fruticultura, 25(3), 453-456.

Vieira, M.R., Correa, L.S., Castro, T.M.M.G., Silva, L.F.S., Monteverde, M.S., 2004. Efeito do cultivo do mamoeiro (Carica papaya L.) em ambiente protegido sobre a ocorrência de ácaros fitófagos e moscas-brancas. Revista Brasileira de Fruticultura, 26(3), 441-445. 